\title{
SISTEM INFORMASI PENDATAAN ANAK PANTI ASUHAN "RIANG" BERBASIS WEBSITE
}

\author{
Menhya Snae \\ Sistem Informasi, STIKOM Uyelindo Kupang \\ email: menhyasnae@gmail.com
}

\begin{abstract}
Childcare Social Institution is a social welfare business institution that has the responsibility to provide social welfare services to neglected children by carrying out assistance and alleviation of neglected children, providing replacement services for parents / guardians of children in fulfilling physical, mental and social needs to foster children so as to obtain broad, appropriate and adequate opportunity for the development of his personality as expected as part of the future generation of the nation's ideals and as people who will actively participate in the field of national development.

Data collection on orphanage children that are not properly implemented is one of the obstacles in checking the number of orphanage children who have not been in homes and who are still in the institution, with education levels, origin, how long they are in the orphanage and various information related to children House.

The problem is how to design and build a system for collecting orphanage children. With the aim of building a website-based orphanage data collection information system. Which is useful for facilitating access to orphanage data, archiving data on orphanages that are more efficient, facilitating the processing of orphanage data.

The results of this study are an information system for data collection of website-based "Riang" orphanage.
\end{abstract}

Keywords: Orphanages, information systems, data collection, foster children, archives

\section{PENDAhUluan}

Keberadaan teknologi dan informasi mendukung peningkatan efisiensi, efektifitas, dan produktivitas bagi berbagai instansi, baik instansi pemerintahan negeri, swasta maupun perorangan atau individual, serta mendorong perwujudan masyarakat yang maju dan sejahtera.

Efektivitas dan efisiensi waktu dalam pengelolaan data sangatlah diperlukan untuk memenuhi kebutuhan akan pemberian pelayanan pengelolaan data dan informasi di suatu badan, institusi, ataupun suatu lembaga tertentu.

Panti Sosial Asuhan Anak adalah lembaga usaha kesejahteraan sosial yang mempunyai tanggung jawab untuk memberikan pelayanan kesejahteraan sosial pada anak terlantar dengan melaksanakan penyantunan dan pengentasan anak terlantar, memberikan pelayanan pengganti orang tua/wali anak dalam memenuhi kebutuhan fisik, mental dan sosial kepada anak asuh sehingga memperoleh kesempatan yang luas, tepat dan memadai bagi pengembangan kepribadianya sesuai dengan yang diharapkan sebagai bagian dari generasi penerus cita-cita bangsa dan sebagai insan yang akan turut serta aktif dalam bidang pembangunan nasional hal ini dituturkan oleh Dinas Sosial (2004).

Panti Asuhan "Riang" adalah sebuah panti asuhan yang berada dalam unit pelaksana teknis daerah pengembangan dan penyantunan sosial di lingkungan dinas sosial propinsi NTT, dengan lembaga usaha kesejahteraan sosial anak yang bertanggungjawab memberikan pelayanan kesejahteraan sosial kepada anak terlantar dalam memenuhi kebutuhan fisik, mental, sosial dan keterampilan pada anak asuh.

Panti asuhan "Riang" memberikan layanan kepada anak-anak yatim piatu dan yang kurang mampu dengan tingkat pendidikan berbeda-beda yakni belum bersekolah, tingkat SD, SMP, dan SMA/K. Pendidikan formal anak panti akan berakhir pada tingkat SMA/K, selain itu anak panti dibekali dengan ketrampilan tambahan seperti bercocok tanam, beternak, menjahit, melukis, bermusik, pelatihan komputer, pertukangan 
dan beberapa keterampilan yang akan menjadi bekal saat sudah tidak berada di pantia asuhan.

Pendataan anak panti yang tidak terasipkan dengan baik adalah salah satu kendala dalam mengecek jumlah anak panti yang sudah tidak berada di panti dan yang masih berada di panti, dengan tingkat pendidikan, asal usul, berapa lama berada di panti asuhan dan berbagai informasi yang terkait dengan anak panti. Permasalahan yang ditemukan adalah bagaimana merancang dan membangun sebuah sistem pendataan anak panti asuhan. Tujuan penelitian ini adalah membangun sistem informasi pendataan anak panti asuhan berbasis website. Serta harapan hasil yang diinginkan yaitu mempermudah pengaksesan data anak panti asuhan, pengarsipan data anak panti yang lebih efisien, mempermudah pengolahan data anak panti.

\section{KAJIAN LITERATUR}

Sistem adalah kumpulan dari elemen-elemen atau komponen-komponen yang berinteraksi untuk mencapai tujuan tertentu. Komponen-komponen atau subsistem-subsistem dalam suatu sistem tidak dapat lepas sendiri-sendiri. Subsistemsubsistem tersebut saling berinteraksi dan saling berhubungan membentuk satu kesatuan sehingga tujuan atau sasaran sistem dapat tercapai [1].

Informasi adalah suatu data yang telah diproses sehingga dapat mengurangi ketidakjelasan tentang keadaan atau suatu kejadian. Sedangkan kata data itu sendiri adalah fakta atau kenyataan yang sebenarnya. Informasi juga dapat didefinisikan sebagai hasil dari pengolahan data dalam suatu bentuk yang lebih berguna dan lebih berarti bagi penerimanya yang menggambarkan suatu kejadian kejadian (event) yang nyata (fact) yang digunakan untuk pengambilan keputusan [2].

Menurut [3] Sistem Informasi adalah sekumpulan komponen terpisah yang berfungsi untuk mengumpulkan, mengolah, menyimpan, dan menyediakan tugas-tugas dalam bisnis. Sistem Informasi merupakan kombinasi teratur apapun dari orang-orang, hardware, software, jaringan komputer, dan sumber daya data yang mengumpulkan, mengubah, dan menyebarkan informasi dalam sebuah organisai. Jadi, sistem informasi adalah sekumpulan komponen yang saling terkait yang berfungsi untuk mengumpulkan, mengolah, menyimpan, dan menyediakan output untuk mencapai tujuan tertentu dalam suatu organisasi.

Menurut [4] sistem informasi manajemen adalah suatu sistem penghasil informasi yang mendukung sekelompok manajer yang mewakili suatu unit organisasi seperti suatu tingkatan manajemen atau suatu bidang fungsional.

Tugas Pokok, Fungsi,Tujuan Panti

1. Tugas Pokok.

Memberikan pembinaan, meliputi: fisik, mental, bakat dan kemampuan serta keterampilan.

2. Fungsi

a. Pusat Pelayanan Kesejahteraan anak meliputi: pemulihan dan penyantunan, perlindungan, pengembangan dan pencegahan.

b. Pusat Informasi dan Konsultasi Kesej ahteraa Sosial Anak, meliputi: pusat data dan penyebaran informasi; ikut serta membantu penyempurnaan kesejahteraan, pengembangan dan peningkatan kesadaran tanggung jawab dan dukungan .

3. Tujuan Pelayanan

- Membantu \& membimbing anak untu $\mathrm{k}$ hidup layak dan penuhtanggung ja wab.

- Terpenuhinya kebutuhan dan perkem bangan anak secara jasmani,rohani d an sosial.

- Membentuk anak dalam mempersiap kan pengembangan potensi dankema mpuan.

- Terbantunya keluarga dan orangtua.

\section{METODE PENELITIAN}

Metode waterfall merupakan metode yang sering digunakan oleh penganalisa sistem pada umumnya. Inti dari metode waterfall adalah pengerjaan dari suatu sistem yang dilakukan secara berurutan atau secara linear. 


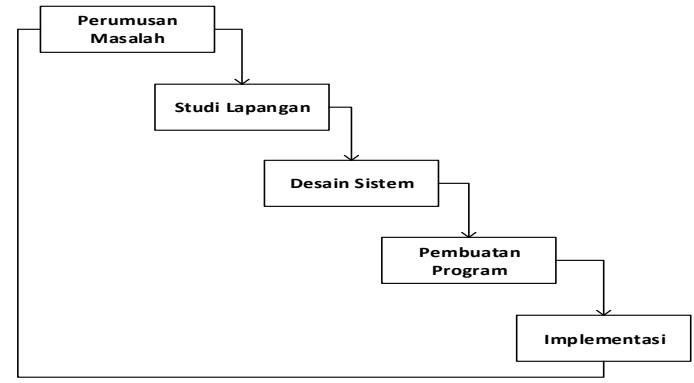

Gambar 1. Diagram Waterfall

\subsection{Peralatan Penelitian}

Peralatan penelitian ini berupa perangkat keras (Hardware) dan perangkat lunak (Software), dengan spesifikasinya sebagai berikut:

Perangkat keras yang digunakan: Laptop Toshiba dengan prosesor Intel ${ }^{\circledR} \quad$ Core $^{\mathrm{TM}}$ I3-2350M CPU @ $2.30 \mathrm{GHz}$ (4CPUs), RAM 2 GB.

Perangkat lunak yang digunakan: OS Windows 8 Enterprise 32 bit, PHP, Web server Apache, Notepad ++, MySQL.

\subsection{Prosedur Analisa data}

Flowchart atau bagan alir adalah bagan (chart) yang menunjukkan alir (flow) di dalam program atau prosedur sistem secara logika. Bagan alir digunakan terutama untuk alat bantu komunikasi dan untuk dokumentasi. Simbol-simbol yang dipakai sebagai alat bantu menggambarkan flowchart. Flowchart dapat didefinisikan sebagai bagan yang menunjukkan arus pekerjaan secara keseluruhan dari suatu sistem. Bagan ini menjelaskan urutanurutan dari prosedur-prosedur atau proses yang terjadi di dalam suatu sistem.

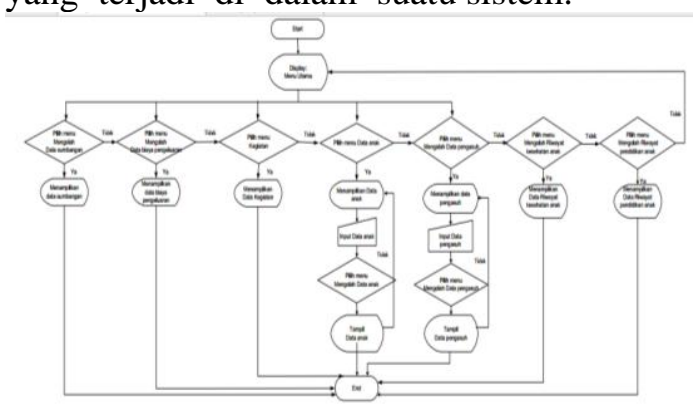

Gambar 2. Flowchart Sistem

Entity relationship diagram adalah suatu model untuk menjelaskan hubungan antara data dalam database berdasarkan objekobjek data yang mempunyai hubungan antara relasi. ERD pada Sistem Informasi pendataan anak panti asuhan.

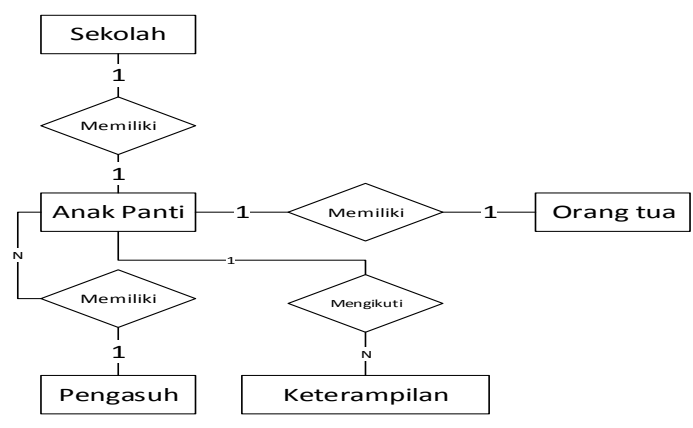

Gambar 3. ERD

Diagram Use Case pada gambar dibawah menggambarkan aktivitas pengolahan data anak panti asuhan.

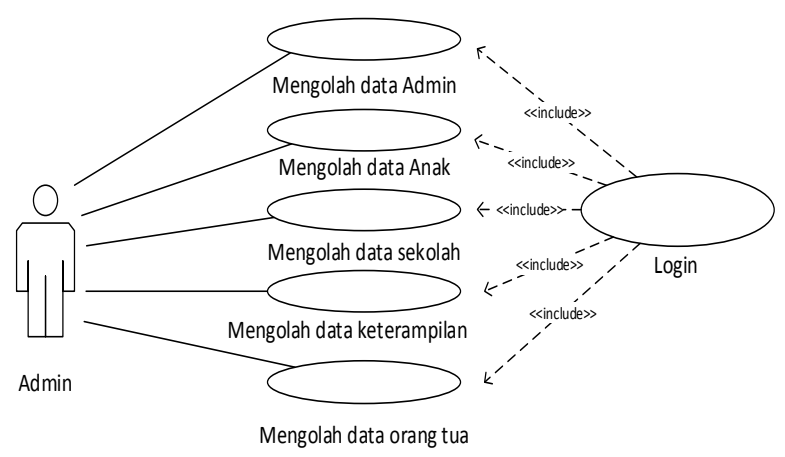

Gambar 4. Use case

\section{Sequence Diagram User}

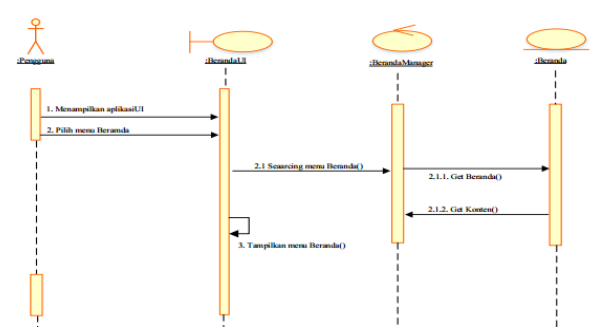

Gambar 5. Sequence diagram user

\section{Halaman Login Admin}

Halaman Login Admin adalah halaman awal ketika petugas atau pengguna khusus mengunjungi halaman utama Administrator. Halaman Login ini digunakan sebagai proses autentifikasi atau proses validasi data Admin sebagai kunci untuk mengakses halaman Administrator. 


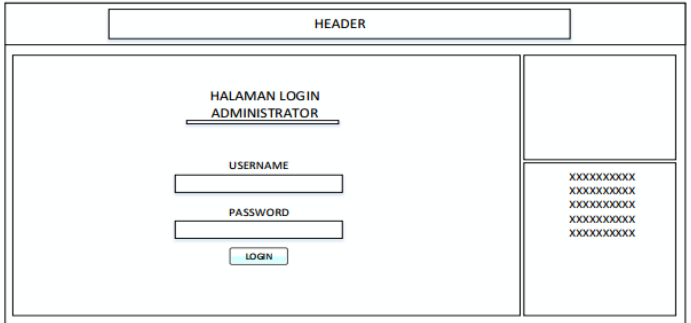

Gambar 6. Halaman Login Admin

\section{HASIL DAN PEMBAHASAN}

\subsection{Implementasi}

Antarmuka Menu utama merupakan antarmuka awal saat aplikasi pengolahan data anak panti asuhan berbasis website dijalankan. Antarmuka ini untuk menampilkan semua menu yang ada didalam website system informasi pendataan. Antarmuka dapat dilihat pada Gambar 7.

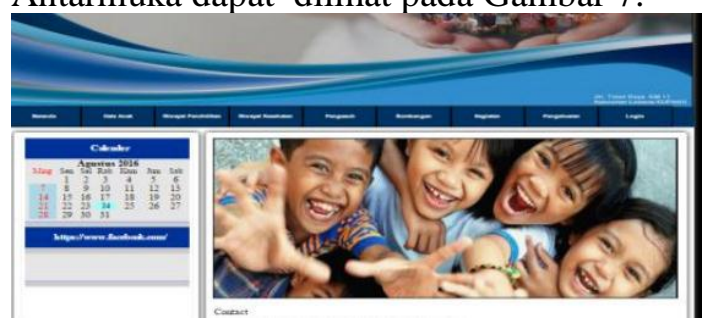

Gambar 7. Halaman Utama

Antarmuka ini digunakan untuk menampilkan dan mengolah data anak Panti Asuhan. Antarmuka ini membatu mendata nama serta identitas anak. Dimana antarmuka ini memiliki tombol simpan data, ubah data serta hapus data.

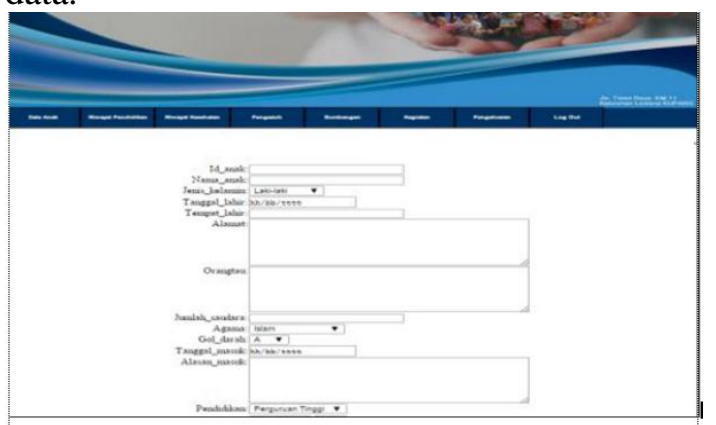

Gambar 8. Antarmuka data anak panti

Antarmuka ini digunakan untuk menampilkan dan mengolah data pengasuh pada Panti Asuhan. Antarmuka ini membatu mendata pengasuh. Dimana antarmuka ini memiliki tombol simpan data, ubah data serta hapus data.

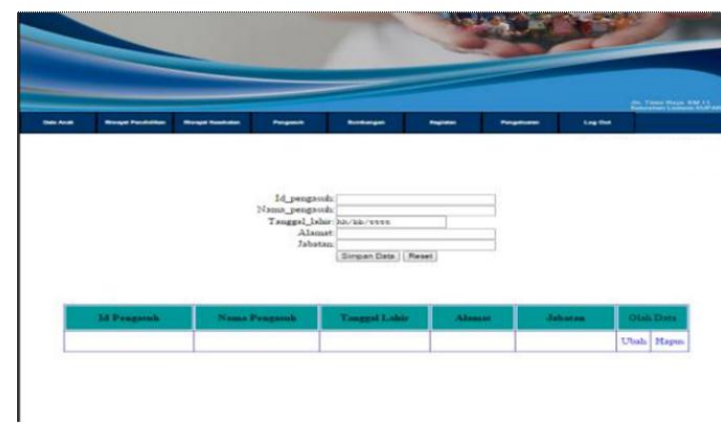

Gambar 9. Antarmuka Pengasuh

\section{Pengujian fungsionalitas sistem}

Pengujian fungsionalitas dilakukan dengan menguji kesesuaian fungsi-fungsi produk dengan output yang dihasilkan. Pengujian dialkukan dengan metode blackbox, yakni mengevaluasi cara kerja sistem. Butir-butir pengujian meliputi deskripsi, prosedur pengujian, masukan, keluaran yang diharapkan, kriteria evaluasi hasil, hasil yang didapat, dan kesimpulan.

Masukan berupa aktivitas awal yang dilakukan penguji terhadap setiap fungsi produk. Nilai untuk kesimpulan terdiri dari valid dan tidak valid. Jika keluaran yang diharapkan sesuai dengan hasil yang didapat, maka perangkat lunak memiliki nilai valid, artinya fungsi sudah sesuai dengan perancangan dan analisis. Sebaliknya bernilai tidak valid jika pada pengujian fungsi terdapat fungsi-fungsi yang tidak sesuai dengan analisis dan perancangan.

\section{KESIMPULAN}

Berdasarkan hasil penelitian dan pembahasan maka dapat disimpulkan bahwa Sistem pendataan anak panti asuhan "Riang" dapat mendata serta mempercepat akses data anak, mempermudah pihak panti asuhan untak mendapatkan informasi tentang data anak panti, dan mempermudah pengelolahan data. Data anak panti akan tersimpan dan terorganisir secara efisien dan efektif. Sedangkan saran yang dapat diberikan adalah:

a. Agar Data anak panti asuhan dapat di kelolah oleh seorang admin yang bertanggungjawab, dan selalu mengupdate tentang perkembangan data anak panti asuhan.

b. Sistem ini masih terbatas pada pendataan data anak panti asuhan. Diharapakan ada pengembangan sistem secara komplek 
sehingga siapapun dapat mengakses data anak panti asuhan.

\section{REFERENSI}

[1] Abdul Kadir. 2014. Pengenalan Sistem Informasi Edisi Revisi.

Andi.Yogyakarta.

[2] Hartono, Jogiyanto.2004. Metodologi Penelitian Bisnis: Salah Kaprah dan
Pengalaman-pengalaman. Yogyakarta: BPFE

[3] Burd S, D, 2007. System Analysis and Designin Changing a World, Fourth Edition. Canada : Thomson. ISBN : 1$41883766-0$.

[4] McLeod,. 2001. Sistem Informasi Edisi 7 Jilid 2. Prenhallindo. Jakarta 